\title{
The Indian Ocean - The Challenges beyond the Plastic Pollution ${ }^{1}$
}

\section{Amrita Dhillon $^{2}$ \& Abhinav Kaushal ${ }^{3}$}

\section{Contribución en la Sección Política Internacional}

Resumen: El calentamiento del Océano Índico resulta ser el mayor contribuyente en línea con la tendencia general de la temperatura media mundial de la superficie del mar, al tiempo que evidencia signos de sobrepesca, que parecen estar aumentando.

Se han vertido en él alrededor de 5-6 millones de toneladas de petróleo -alrededor del 40\% del derrame total de petróleo en las aguas del mundo-, mientras que las presiones humanas (población, infraestructura urbana, etc.) ponen en peligro cada vez más los ecosistemas marinos subyacentes, que sustentan la pesca de la región y otras amenazas incluyen un aumento acelerado del nivel del mar en él, que representa una amenaza inminente para los estados costeros.

Teniendo en cuenta lo mencionado, esta nota aborda el tema de la región del Océano Índico / IOR, una de las ubicaciones estratégicas relacionadas con la paz, la seguridad y el comercio, desde la perspectiva de su papel con respecto al cambio climático y las acciones y reacciones de los países a su alrededor.

Se concluye que la contaminación marina es un problema grave, que causa el deterioro de los recursos en el Océano Índico y aunque los países de la zona invierten una gran cantidad de dinero para combatirlo, ello no resuelve la falta de conciencia entre las masas. Los esfuerzos de las organizaciones regionales, aunque son notables, parecen superficiales y carecen de un impacto significativo, mientras que también se observa la necesidad de innovación en los métodos de implementación para reducir / reciclar los desechos, minimizar los derrames de petróleo y monitorear la vida acuática.

\section{Introduction}

IOR, or Indian Ocean region, said to be one of the strategic locations when it comes to peace, security and trade. Stretched in an area of 70.56 million square Kilometre, the vast

\footnotetext{
1 This article contains no conflict of interest between authors.

${ }^{2}$ Amrita Dhillon is the Founding Editor of The Kootneeti Magazine. She is also an Honourary Analyst at Equilibrium Global.

3 Abhinav Kaushal is the Project Head at The Kootneeti Español. He is also an activist working with the organisations promoting Sustainable Development Goals by the United Nations. He is having a special interest on the SDG - 14 (Life below water). E-mail: abhinav.akaushal@gmail.com
} 
water body touches the shores of Asia in the North, Africa in the West, Australia in the East and Antarctica in the South.

Over the centuries the Ocean helped to settle many civilisations, flourished many trades and endless voyages to explain the nature of the earth.

Amid all this fascinating narration, the saddest part comes as the disastrous human attitude towards the Ocean.

A recent study by the University of Texas shows that the climate of the region is believed to be a driving factor in the climate shift in future. It also shows how the researches shifted their narratives from the Pacific revolving theories and indicated the possibility of the IOR being a greater factor in driving climate change during the last ice age. The research also hints towards the possibility of disruption of the tropical climate again in the coming future, and it may have a role for the Indian Ocean (India Today Web Desk, 2018).

This huge body of water possesses a great significance as compared to all other oceans on this planet due to a notable spreading of the bottom and intermediate water towards the equator.

Despite being a region of high importance, climate factor mostly neglected by the countries around it. If we believe reports by Oceanographer Marcus Eriksen then it could be observed that the Indian Ocean is the second-most polluted ocean on this planet with more than one trillion pieces of plastic waste are floating around the Indian Ocean.

According to a survey of Plastic pollution, published in the journal Scientific Reports estimates 414 million pieces of plastic - including nearly a million shoes and around 370,000 toothbrushes - have been found washed ashore on the beaches of remote Cocos (Keeling) Islands in the Indian Ocean (PTI, 2019).

The same report estimates that the beaches on the islands are littered with 238 tonnes of plastic.

However, plastic is not the only problem this huge water body got, but air pollution, heating-up of marine waves, aquatic life damage, Oil spills add a few more to the list.

Considering the above mentioned, this note approaches to the issue of the Indian Ocean region/IOR, one of the strategic locations related to peace, security and trade, from the perspective of its role concerning climate change and the actions and reactions from countries around it on this theme.

\section{The rise in Temperature and its impact}


The Indian Ocean warming turns out to be the largest contributor in phase with the overall trend in the global mean sea surface temperature. Indian ocean is heating $\left(0.11^{\circ} \mathrm{C}\right.$ per decade) faster than the Atlantic Ocean $\left(0.07^{\circ} \mathrm{C}\right.$ per decade) and the Pacific Ocean $\left(0.05^{\circ} \mathrm{C}\right.$ per decade), and the surface temperature of the Indian Ocean will rise by $0.60^{\circ} \mathrm{C}$ by 2050 (Koll Roxy, Ritika, Terray \& Masson, 2014).

A recent study by Nature's climate change shows the rising temperature in the Indian ocean is affecting Atlantic's ocean current. Atlantic currents plays a key role in determining the weather across the world (Hu and Fedorov, 2019).

The study suggests AMOC - Atlantic meridional overturning circulation which is also referred to as Atlantic Conveyor Belt is one of the Planet's largest water circulation systems where ocean currents move warm, salty water from the tropics to regions further north, such as western Europe and sends colder water south.

It serves in distributing heat and energy around the planet, as the warm water it carries releases heat into the atmosphere, and in absorbing and storing atmospheric carbon.

AMOC believed to be stable from past centuries, but a recent instability is noticed in the last 15 years. This could have dramatic consequences for Europe and other parts of the Atlantic rim.

Temperature rise in the Indian Ocean generates additional precipitation, which, in turn, draws more air from other parts of the planet, including the Atlantic region. The higher level of precipitation in the Indian Ocean will reduce precipitation in the Atlantic and increase salinity in the waters, the researchers explained.

This saline water in the Atlantic, as it comes north via AMOC, will get cold much quicker than usual and sink faster, acting "as a jump start for AMOC, intensifying the circulation"

\section{Marine life and the challenges}

Fishing as a livelihood has grown remarkably in recent decades. According to the Food and Agriculture Organization (FAO), from less than 900,000 tons in 1950, Indian Ocean marine fisheries supplied 11.3 million tons of fish in 2010 , about 14.6 percent of the total world catch.

However, if the health of specific stocks, to be observed then signs of over-fishing are increasing. Growing numbers catches may reflect not sustainable trends but a largely unregulated enlargement into new areas and species (FAO, 2018). Recently, a Fisheries Commission conducted assessments of 140 species in the Western and the Southwest Indian 
Ocean, concluding that $65 \%$ of stocks were fully exploited in 2010 , and $29 \%$ were overexploited (Michel and Sticklor, 2012).

Illegal and unreported fishing complicate efforts to efficiently monitor and oversee the region's fisheries. Illegal and unreported fishing often occurs at the expense of local fishers. The FAO, for instance, estimates that 700 foreign vessels were fishing without a license in Somali waters over recent years. Tragically, foreign ships were thus likely illegally removing more protein from Somali waters than they were providing to Somalia in food aid and famine relief.

\section{Oil Spills and other discharges}

Around 5-6 million tonnes of petroleum and oil have been discharged into it-which is around $40 \%$ of the total petroleum spill in the world's waters.

Oil can have a smothering effect on marine life, fouling feathers and fur. It is a toxic poison that birds and mammals often ingest while trying to clean themselves. Fish absorb it through direct contact and their gills. The fumes and contact with oil can also cause nausea and health problems for people in affected areas.

Other discharges include heavy metals and their salt's continental wash. In addition to the municipal and domestic sewage and a large number of harmful chemicals of agricultural importance and industries are continuously coming to the Indian Ocean.

\section{Human interaction with Marine life}

The human pressures increasingly endanger the underlying marine ecosystems that sustain the region's fisheries. Coastal development for the ports, roads, and urban infrastructure is damaging mangroves, coral reefs, and other habitats. Asian coastlines, for example, lost around 1.9 million hectares of mangroves between 1980-2005, while African coastline lost another half million (Strong and Minnemeye, 2015). Pollution, destructive and inappropriate fishing practices (such as the use of dynamite and poisons), coral mining for construction materials, and coral bleaching have already destroyed or critically endangered as much as two-thirds of the Indian Ocean's 12,070 km2 of coral reefs.

\section{Rising Sea level}

Another threat coming from global warming includes an accelerated rise of the sea level in the Indian Ocean, which is slightly higher than the global estimate of $3.2 \mathrm{~mm}$ per year. 
Rising sea level, pose a looming threat to coastal states. Even modest increases in sea level are likely to worsen existing environmental challenges on the islands, such as determined flooding from waves often generated by storms far away.

The very fair example for this could be the Maldives, one of the flattest countries on Earth is extremely vulnerable to rising sea level and faces the exceedingly possibility that the majority of its land area will be submerged under the Indian Ocean by the end of this century.

Given scenarios for global warming emissions, Maldives projected to experience sealevel rise about 1.5 feet-and to lose some 77 percent of its land area by the end of this century. If sea level were instead to rise by 3 feet, the Maldives could be almost completely submerged by about 2085 .

\section{Conclusion}

Marine pollution is a grave issue, which causes deterioration of resources in the Indian Ocean. Eventually, it will lead to a destruction of habitat, acute poisoning by toxic wastes, adverse alteration of water quality and bacteriological and viral contamination.

Countries around IOR are spending around $\$ 100$ million to fight this disastrous issue; however, the major missing link in the entire process is the awareness among the masses.

Efforts of Regional Organisations such as SAARC Disaster Management Centre over a decade, while noteworthy, are viewed as superficial and lacking in meaningful impact (Andharia, 2017/2019).

Innovation is another pressing challenge for the governments in the IOR countries, who are unable to implement methods to reduce/recycle the waste, minimising the oil spills and monitor the aquatic life.

\section{References}

Andharia, J. (2017/2019). Disaster Management In IORA: Traversing Rhetoric \& Reality. The Kootneeti (December 24/September 18). Retrieved from https://thekootneeti.in/2017/12/24/disaster-m-t-1/

FAO (2018). The State of World Fisheries and Aquaculture 2018 - Meeting the sustainable development goals. Rome: FAO. Retrieved from http://www.fao.org/3/i9540en/i9540en.pdf

Hu, Sh. and Fedorov, A. V. (2019). Indian Ocean Warming Can Strengthen The Atlantic Meridional Overturning Circulation. Climate Change (September 16). Retrieved from https://www.nature.com/articles/s41558-019-0566-x 
India Today Web Desk (2018). Indian Ocean May Be The Reason For Climate Shift In Future, Says A Study. India Today (December 13). Retrieved from https://www.indiatoday.in/education-today/gk-current-affairs/story/indian-oceanmay-be-the-reason-for-climate-shift-in-future-says-a-study-1408650-2018-12-13

Michel, D. and Sticklor, R. (2012). Plenty Of Fish In The Sea? Food Security In The Indian Ocean. The Diplomat (August 24). Retrieved from https://thediplomat.com/2012/08/plenty-of-fish-in-the-sea-food-security-in-theindian-ocean/

PTI (2019). 414 Million Plastic Pieces Found On Indian Ocean Islands: Study. The Economic Times (May 17). Retrieved from https://economictimes.indiatimes.com/news/environment/pollution/414-millionplastic-pieces-found-on-indian-ocean-islandsstudy/articleshow/69370183.cms?from $=\mathrm{mdr}$

Roxy, M; Ritika, K; Terray, P. \& Masson, S. (2014). The Curious Case of Indian Ocean Warming. American Meteorological Society, 27 (22), 8501-8509. Retrieved from http://www.rocksea.org/bin/research/roxy_indian_ocean_warming_jclimate_2014. pdf

Strong, A. and Minnemeye, S. (2015). Satellite Data Reveals State Of The World'S Mangrove Forests. World Resources Institute (February 20). Retrieved from https://www.wri.org/blog/2015/02/satellite-data-reveals-state-world-s-mangroveforests 